\title{
Restricted Decentralization: A Review of Supreme Court Decisions on Philippine Local Autonomy
}

\author{
Glenn Niño M. Sartillo ${ }^{1 *}$ \\ \{glenn.sartillo@lpu.edu.ph ${ }^{1}$ \} \\ Lyceum of the Philippines (LPU), Manila Campus, Muralla St, Intramuros, Manila, 1002 Metro \\ Manila, Philippines. ${ }^{1}$
}

\begin{abstract}
This paper attempts to review how the Supreme Court interpreted local autonomy in the Philippines through the decisions it rendered from 1991 to 2016, in the hope of outlining and summarizing the meaning and extent of local autonomy within the framework of the 1987 Constitution, the Local Government Code of 1991 and other laws. More particularly, the paper examines the interplay between local autonomy, on the one hand, and executive and legislative powers on the other.
\end{abstract}

Keywords: Restricted Decentralization; Supreme Court Decisions; Philippine Local Autonomy.

\section{Introduction}

In 1991, Congress enacted into law Republic Act 7160, otherwise known as the Local Government Code of 1991, which is described as "by far the most radical and far-reaching policy" aimed at addressing a politico-administrative system that is over centralized in Manila [1]. By devolving to local government units certain responsibilities, such as the enforcement of certain regulatory powers, as well as by increasing financial resources available to local government units, the Code is said to have further enhanced local autonomy in the Philippines.

Not everyone, however, found comfort in such reform. At one side, there were those who wanted to retain as much power as possible, but acknowledge that they bit-off more than they could chew. While recognizing the potential rewards from the new setup, the national government would reasonably have to firmly hold its grip in the rope of power and influence in the political tug-of-war, if only to remain as relevant as before. At the other extreme side, the enactment was considered a lukewarm response to the centuries-old deprivation of power from the countryside. Such consolation prize would not be acceptable for those who deem federalism as a, if not the solution, to the state's backwardness. If the republican design of the Philppine government were to give the cue, the election to the presidency in 2016 of Rodrigo R. Duterete, a former city mayor of Davao, would be an indication of the electorate's desire to shift to a federal government. True to its promise during the electoral campaigns, the Duterte administration has been actively and seriously advocating for federalism to be pursued through constitutional reforms.

2016 marks the 25th anniversary of the enactment of the Code. It has already been a while that the political makeup of the Philippines featured a degree of local autonomy, the RA 7160 style. The journey is not completely smooth, but one interspersed with actual controversies in the application and operation of local autonomy. As the highest court in the judicial 
department, the Supreme Court has let the hammer fall to settle the legal controversies on local autonomy that reached its bench, promulgating the authoritative interpretation of relevant constitutional and legal provision. The jurisprudence laid down by the Supreme Court provides guidance on how different actors and institutions should sway the sword of local autonomy within the parameters of the constitution and other laws.

\section{Local Autonomy, Decentralization, And Local Governments}

Local autonomy is defined by Tapales as "the degree of self-determination exercised by a local government unit vis-à-vis the central government." She further argues that "( $\mathrm{t}$ )o attain local autonomy, a necessary prerequisite is decentralization" [2].

Raul P. De Guzman defines decentralization as the "systematic and rational dispersal of power, authority and responsibility from the center to the periphery, from top to lower levels, or from the national to local government" [3]. And one of the strongest arguments for decentralization is that it works towards development. Particularly referring to decentralization efforts in Third World Countries, Cheema and Rondinelliargue that decentralization policies are more likely to achieve development because they can overcome the severe limitations of centrally controlled national planning, cut through massive amounts of red tape, increase government sensitivity to local interests and challenges, and provide greater representation for different groups in development decision-making, potentially leading to greater equity in the allocation of government resources. [4].

The responsiveness of local governments remains to be a most powerful underpinning of decentralization. Local governments enjoy a relatively higher level of sensitivity to the specific needs of the people at the local level as compared to the national government. Through local governments, decisions are made according to needs of the locality and are located closer to the scene of action. Moreover, decision making processes can be hastened and made relatively easier making development goals easier to achieve. As such, decentralization improves efficiency of government response to the needs of the people, and is capable of addressing poverty, improving healthcare and education, among others [5, 6]. Decentralization is also often intended as a positive policyinstrument for accommodating a region's unique culture and history, apart from predominantly to protect minorities andmanage conflict [7].

Decentralization varies across political systems, depending largely on the degree of autonomy local governments enjoy. Under the Code, Brillantes lists devolution as among the three major forms of decentralization, and has always been associated with the local autonomy. As compared to the other two forms, deconcentration and debureaucratization, devolution is political in nature, involving "transfer of powers and authorities to lower level political or local government units."

Said Tapales: An autonomous local government is one which has attained a measure of decentralization, or devolution. This involves greater taxing powers, as well as greater prerogative to determine priorities in the administration of certain services or the earmarking of resources. [2] 


\section{Brief Historical Account Of Local Autonomy In The Philippines}

Local autonomy is relatively not new in the Philippines. Prior to the 1987 Constitution and the Code, there have been policies that are supportive of giving more powers to the local government. In 1983, the Maura Law enacted by the colonial government established tribunales, municipales and justasprovinciales. In 1899, under the short-lived First Philippine Republic, the Malolos Constitution mentioned "decentralization" and "administrative autonomy," and instituted municipal and provincial assemblies. Even the colonial government that administered the Philippines during the American occupation promulgated policies that are pro-local autonomy such as those that organized municipal and provincial councils based on general suffrage, and Act 1396 that organized provincial governments [2].

The 1935 Constitution, which governed the Commonwealth period (1935-1946), provided for the status of local governments vis-à-vis the President:

The President is in charge of all federal branches, bureaus, and agencies, as well as exercising general supervision over all municipal bodies as required by law, and ensuring that the laws are diligently carried out.

What is clear is that the constitution provided for a limited power of the President over the local governments, in contrast to what he could exercise over the executive branch. Citing Ocampo and Panganiban, Brillantes notes that this "was a compromise measure substituted for the stronger guarantee of local autonomy that was proposed during the constitutional convention." [2]

Pursuant to the constitutional fiat, the Congress in 1959 passed RA 2264, "An Act Amending the Law Governing Local Governments by Increasing Their Autonomy and Reorganizing Local Governments." In the same year, RA 2370, otherwise known as the Barrio Charter Act, was also passed. It granted autonomy to barrios in the Philippines, which were regarded under the law as quasi-municipal corporations. In 1967, another landmark legislation was passed, RA 5185 or the Decentralization Act of 1967, which aimed to:

... grant municipal councils more flexibility and ability to adapt to their people's demands and foster their prosperity and welfare, as well as a more equal and systematic distribution of governmental powers and wealth. At that end, municipal councils will be entrusted with carrying out certain tasks that are better administered at the local level, and they will be given as much autonomy and financial capacity as is necessary to carry out these duties more effectively.

Local autonomy was given more importance in the 1973 Constitution, if the space it apportioned to local government is indicative of such intent. For the first time, an entire article was devoted to Local Government, aside from the basic principle of government under Section 10, Article II that:

The state must guarantee and promote the independence of local government units, especially barangays, in order for them to fully develop as self-sufficient communities.

The 1973 Constitution mandated the BatasangPambansato enact a local government code that defines "a more responsive and accountable local government structure with an effective system of recall, allocating among the different local government units their powers, responsibilities, and resources,..." Local governments were likewise granted "power to create its own sources of revenue and to levy taxes, subject to limitations as may be provided by law." In response, the legislature enacted Batas Pambansa337 or the Local Government Code of 1983, which reemphasized the policy of the state to "guarantee and promote the autonomy of local government units." However, "(f)ull autonomy could not be realistically implemented under the authoritarian regime." 


\section{Constitutional And Legal Framework Of Local Autonomy In The Philippines}

This section discusses the current framework of local autonomy in the Philippines, which is primarily provided for by the 1987 Philippine Constitution, and the Local Government Code of 1991.

Constitutional Policy on Local Autonomy

More pronounced legal provisions supportive of local autonomy can be found under the 1987 Constitution. Article II, Section 25 declares as one of the state policies that "(t)he State shall ensure the autonomy of local government."

The entire Article $X$ is dedicated to Local Government. Section 2 states that "( $(t)$ he territorial and political subdivisions shall enjoy local autonomy." Meanwhile, Section 3 provides:

The Congress shall implement a local government framework that addresses a more responsive and accountable local government model through a decentralization program that implements effective recall, initiative, and referendum systems, distributes powers, responsibilities, and resources among the various local government units, and establishes qualifications, election, and appointment procedures for local government officials.

The Local Government Code of 1991

Pursuant to the constitutional mandate, Congress enacted RA 7160 or the Local Government Code of 1991, which became effective on 01 January 1992. The following are some of the Code's key features, as defined by Brillantes:

1. It delegated to local government units responsibility for a number of social services that were previously handled by the federal government.

$$
\mathrm{X} \text { XX }
$$

2. It further transfers responsibilities for the regulation of such administrative authorities to municipal governments.

$$
\mathrm{x} \mathrm{xx}
$$

3. The Code further establishes the legislative and administrative framework for civil society involvement in local government.

$\mathrm{x}$ xx

4. The Code boosts the amount of money allocated to municipal governments (LGUs). The Code specifically: (a) expands their taxation powers; and (b) provides them with a specific share of the national resources exploited in their region.,...; and (c) increases their share of national income, from a low of $11 \%$ to as high as $40 \%$ of internal revenue allotments (IRA). The Code also gives municipal governments more flexibility in terms of generating revenue from city fees and charges.

$$
\mathrm{x} \mathrm{xx}
$$

5. Finally, the Code provided the basis for more entrepreneurial city councils to emerge and flourish.

\section{Interpreting Local Autonomy}

The following discussion hinges on the jurisprudence on local autonomy laid down by the Supreme Court from 1991, the year RA 7160 was enacted, to 2016, essentially covering 25 years. The cases were identified through the help of LexLibris, which generated results on the 
topic "local autonomy" appearing on the syllabus of cases. As the latest update of LexLibris only allows the listing of cases as per syllabus until 2006, the cases from 2007 until 2014 were identified through the Supreme Court Reports Annotated Quick Index-Digest. Cases decided in 2015 and 2016 were again identified through the use of LexLibris, by searching not through the syllabus but the text of the cases.

Jurisprudence on the Constitutional Policy of Local Autonomy Prior to the Enactment of RA 7160

Interestingly, the Supreme Court promulgated rulings in 1991 that made use of the rather motherhood constitutional provision on local autonomy, without waiting for Congress to enact the enabling law. As cited in the landmark case of Manila Prince Hotel v. GSIS [8], "unless it is expressly provided that a legislative act is necessary to enforce a constitutional mandate, the presumption now is that all provisions of the constitution are self-executing." It is clear that the 1987 Constitution requires the enactment of the local government code, and by inference, the state policy on state autonomy may not be considered self-executing.

In San Juan v. CSC, the Court took a different path. Resolving the issue on the validity of the appointment of a Provincial Budget Officer made in 1988 by the Undersecretary of the Department of Budget and Management (DBM), the Court upheld the imperative to secure first the recommendation made by the Provincial Governor. Making reference to the constitutional policy of local autonomy, the Court articulated:

The validity of one Provincial Budget Officer's position isn't the only issue before the Court. The dispute between the Secretary of Budget and Management and the Governor of Rizal, the Philippines' most populous province, revolves around the implementation of a core constitutional strategy and principle: local autonomy. It is necessary to adhere to the specific directive on local autonomy. When a law is seen from two perspectives, one that favoursMalacaang'scentralised control and the other that favours territorial sovereignty, the scales tip in favour of democracy.

$\mathrm{x} \mathrm{xx}$

The Civil Service Commission went against the letter and intent of the constitutional provisions on local autonomy when it treated the Provincial Governor's advising authority as solely advisory. The task of genuine regional democracy is blocked and put back if the DBM Secretary jealously hoards all discretionary authority and lacks the ability of local councils to develop self-reliance and resoluteness in the management of their ownfunds.

$\mathrm{x} \mathrm{xx}$

Our national authorities must respect not only the fundamental guarantees of local sovereignty, but also the spirit of liberty that these laws are founded on [9].

Meanwhile, the Court had the occasion in Basco v. PAGCOR to clarify the meaning of the principle of local autonomy. Holding that "the matter of regulating, taxing or otherwise dealing with gambling is a State concern and hence, it is the sole prerogative of the State to retain it or delegate it to local governments," the court cited that "the principle of local autonomy under the 1987 Constitution simply means 'decentralization.' ... It does not make local governments sovereign within the state or an 'imperium in imperio." " [10]

Challenged in Ganzon v. CA was the power of the President to suspend and/or remove local officials. The petitioners argued that the President is no longer entitled to wield the power of suspension and/or dismissal over local authorities under the 1987 Constitution, which was intended to "strengthen self-rule by local authority units" and to rid the President of the power of control over local councils by repealing the word "as may be provided by law," a proviso present in the 1935 Constitution. They contend that such deletion is significant "since 
(1) the power of the President is 'provided by law' and (2) hence, no law may provide for it any longer." The Court disagreed:

Despite the alteration in the constitutional language, the Court believes that the charter does not mean to strip the legislature of its power or the President of her prerogative to impose regulatory penalties on elected authorities, as provided by existing law. The omission (of "as may be granted by law"), in our view, serves only to emphasise local councils' autonomy from Congress and to minimize Congress' "control" over local government matters.The Constitution, on the other hand, did not wish to deprive the legislature of any jurisdiction over municipal corporations, especially in matters of discipline, for the sake of local autonomy.

$\mathrm{x} \mathrm{xx}$

The petitioners believe the Constitution has given the President only supervisory rights, without the power of prosecution, and has refused her jurisdiction, which includes disciplinary authority. It's a misunderstanding, since "supervision" is not incompatible with regulatory power under the law... [11]

The Court went on to explain the concept of local autonomy, an articulation that was made reference in a number of subsequent cases:

Local autonomy, as defined by the Constitution, means establishing a more open and transparent local government mechanism in a decentralised framework. As we have seen, the Constitution serves only to break the national government's monopoly on local government affairs, and to free local councils from Manila's imperialism, as put by political supporters.Autonomy, on the other hand, does not plan to break the partnership and interdependence between the central government and local government units, nor does it intend to usher in a federalist system. That is not where the Charter can go. Local governments are governed by the Constitution, but only to a certain extent, and for no other reason than to improve self-government, despite the confusion.

Decentralization, as we saw in one scenario, includes devolution of national administration but not authority to local levels. As such:

Decentralization of administration or decentralization of authority is now synonymous with autonomy. Decentralization of administration happens as the federal government delegate governmental responsibilities to political subdivisions in order to expand the reach of government authority, make local councils more open and responsible, ensure their complete growth as self-sufficient societies, and make them more productive participants in national development. Simultaneously, it relieves the central government of the responsibility of managing local politics, allowing it to focus on national issues. They are supervised by the President in general, but only to maintain that municipal issues are conducted in accordance with the constitution. He doesn't have much influence on their actions in the way that he can't make their decisions for them.

Decentralization of power, on the other hand, entails the handing over of state power to local governments. The autonomous government is free to chart its own course and shape its own direction in this case, with limited intervention from the central government. According to one constitutional analyst, decentralization of power is equivalent to self-immolation since provincial governments are held accountable to their citizens rather than central authorities.

These decisions brought to fore that the constitutional policy on local autonomy, while more aggressive, remain circumscribed. Equally important, the rulings may have set the tone for future interpretations with respect to the power of the President and the legislature. We now turn to these issues.

Local Autonomy and the Executive 
Preliminarily, instructive to dynamics between executive power and local autonomy is a review of the relevant provisions in previous constitutions. As quoted above, the 1935 Constitution effectively distinguished the kind of executive power the President could exercise over local government units, i.e. supervision. Citing Tecson v. Alas, the Court in San Juan v. CSC further clarified that such supervision is "both general and circumscribed by statute":

... The presidential integrity does not even extend to general oversight, but to general supervision as defined by statute. As a result, he was unable to go beyond the relevant constitutional provisions, which bind and restrict his discretion in the matter. Furthermore, as Justice Padilla had previously ruled in Mondano V. Silvosa (97 Phil. 143 [1955]), which the current Chief Justice alluded to in his decision in the Hebron case, oversight should not extend beyond that "overseeing or the power or authority of an officer to see that subordinate officers perform their duties. If the latter fail or neglect to fulfill them the former may take such action or step as prescribed by law to make them perform their duties." (Ibid, pp. $147-$ 148) Control, on the other hand, "means the power of an officer to alter or modify or nullify or set aside what a subordinate had done in the performance of their duties and to substitute the judgment of the former for that of the latter."

Clearly, the President, even under the 1935 Constitution, does not have control over local government units.

While there was no expressed mention regarding the relationship between the executive and local government units in the 1973 Constitution, it nevertheless affirmed local autonomy under Article II, Section 10. A case noted that similar to the 1935 Constitution, the 1973 Constitution likewise limited the President's power over local government units to supervision and excluded the power of control [12].

Explicitly resurrected in the 1987 Constitution, through a separate provision, is the President's power of general supervision over local governments. Article X, Section 4 states: "The President of the Philippines shall exercise general supervision over local governments," which must be read alongside Article II, Section 25: "The State shall ensure the autonomy of local governments."

In a line of cases, the Supreme Court interpreted the constitutional provisions in favour of local government, construing certain acts of the President and his agents as running afoul the constitutional policy of local autonomy. As noted above, one of the earliest cases that sustained local autonomy vis-à-vis the power of the Executive over the appointment of a local official is San Juan v. CSC. Meanwhile, dealing with a controversy that revolved around the authority of the Local Government Secretary over the katipunanngmga barangay, the Court held that he does not have the authority to "pass upon the validity or regularity of the election of the officers of the katipunan," as it is tantamount to control over local government units permitting him to "interfere in a purely democratic and non-partisan activity aimed at strengthening the barangay as the basic component of local governments so that the ultimate goal of fullest autonomy may be achieved." [13]

In The National Ligangmga Barangay v. Paredes, the Supreme Court ruled that the Secretary of the Department of the Interior and Local Government (DILG) as the President's alter ego would not have the authority to name a temporary caretaker of the Ligangmga Barangay. The act of the DILG in electing the respondent as president of the Liga's Caloocan Chapter prior to the newly-scheduled elections, when the petitioner was already president, was found to be in excess of oversight and an exercise of power [14].

The withholding of a portion of the Internal Revenue Allotment (IRA) cannot be validly ordered by the President even in the pretext of solving economic difficulties. In Pimentel v. Aguirre, President Ramos issued Administrative Order No. 372, Section 4 of which ordered 
the withholding of $10 \%$ of the IRA of LGUs. It was struck down by the Court for encroaching fiscal autonomy of local governments, saying that "purposes must be carried out by legal methods." [15]

Local fiscal autonomy was again discussed and upheld in a more recent case of The Province of Batangas v. Romulo, wherein a program known as Local Government Service Equalization Fund (LGSEF) aimed at facilitating "the process of enhancing the capacities of local government units in the discharge of the functions and services devolved to them..." as contained in the General Appropriations Acts of 1999, 2000 and 2001 was declared violative of the constitutional precept on local autonomy. More particularly, it contradicted Article X, Section 6 of the Constitution, which provides that LGUs shall have just share in national taxes that must be determined by law and be automatically released to LGUs. However, the LGSEF could not be released without the approval of an Oversight Committee. For the Court, to subject to conditions imposed by the Oversight Committee the distribution and release of the LGSEF, which is part of the IRA, is constitutionally impermissible, as the same makes the release not automatic [16].

The Court likewise declared null and void a Local Budget Circular of the DBM, which limited additional honorarium that local governments can give to national government officials and employees assigned in their localities to rates not exceeding $\mathrm{P} 1,000$ in the provinces and cities, and $\mathrm{P} 700$ in municipalities. Aside from failing to comply with the publication requirements, the issuance was declared to have gone beyond the law it seeks to implement, emphasizing that interference of the President or any of his alter egos can be justified if the affairs and activities of local governments are contrary to law. Said the Court:

The law that supposedly acts as the legislative foundation for LBC 55, Section 458, art. (a)(1)(xi), of RA 7160, requires judges to be given extra allowances whether the city government's resources enable it. The clause in question would not provide for a specific upper limitation on the extra allowances given to judges. Thus, we do not need to focus on the fact that a city government's finances can permit the award of additional allowances greater than P1,000 if the city government's revenues exceed its annual expenses. [17]

The preceding cases should not necessarily create an impression that Court always favors local autonomy in relation to the power of the executive. A case in point is Ganzon v. CA, as already discussed. To reiterate, the Court articulated that despite the change in constitutional language, the 1987 Constitution "did not intend to divest the ... President of her prerogative as conferred by existing legislation to provide administrative sanctions against local officials." There, the Court held that the power of the Secretary of Local Government to suspend local government officials is within the contemplation of the meaning of supervision. Importantly, the court stipulated the following rules insofar as the constitutional principle of local autonomy is concerned:

1. Local autonomy, as defined by the Constitution, entails a decentralization of administration rather than authority, with local authorities remaining responsible to the central government in accordance with the law;

2. The new Constitution does not prescribe federalism;

3. The change in constitutional language (in relation to the supervision clause) was intended only to deny legislative authority of municipal governments; it did not exclude them from legislative legislation as long as such regulations were compatible with the basic principle of autonomy;

4. Since local councils are still responsible to the national government, the latter can take disciplinary measures against local officials in accordance with the legislation and the procedures set out therein. 
5. "Supervision" and "investigation" are not inconsistent terms; "investigation" does not signify "control" (which the President does not have)...

While a local government unit can regulate the conduct of business, it cannot regulate practice of profession, like optometry, as the latter function is "within the exclusive domain of the administrative agency specifically empowered by law to supervise the profession..." This was the ruling in Acebedo $v$. CA, where the Court held as invalid the conditions imposed by the Office of the City Mayor of Iligan as the same pertains to the practice of optometry [18]

In a fairly recent case of Mangune v. Ermita, the Court upheld the authority of the President to devolve the Taguig-Pateros District Hospital from the Department of Health to the City of Taguig. This was considered part of the authority of the President to reorganize offices under the executive department [19].

Local Autonomy and the Legislature

By strengthening local autonomy, never did the 1987 Constitution intend to setup a federal regime of centre-periphery relations, but one that is unitary. In contrast with the federal government where sovereignty and not just power is shared between governments, say central government and local government, within a single state, the unitary form exclusively concentrates sovereignty with the central government. Subnational levels may implement, and even make policy, but with leave of the central government [20].

Working within the parameters of the constitutional principle of local autonomy, Congress is clearly empowered by the 1987 Constitution to exercise control over local government units. Article X, Section 3 states:

The Congress must pass a local government code that provides a more sensitive and responsible local government system by decentralization and efficient recall, petition, and referendum processes, distributes rights, duties, and services among the various local government entities, and determines local officials' credentials, election, and appointment..

As earlier pointed out, such local autonomy means decentralization. The Court in Lina v. Paño elucidated:

The most recent articles in the Constitution strengthening local autonomy policy have not weakened the basic relationship between the national legislature and local government units. Without wishing to belittle the approach, we should say confidently that Congress maintains jurisdiction of local government units, although to a far lesser extent than under previous Constitutions. The ability to build also requires the ability to kill. The ability to give requires the ability to withhold or recall.True, the Constitution contains several noteworthy innovations, such as the direct grant of taxing authority to local government bodies (citing Art. X, Sec. 5, Constitution), which cannot yet be revoked by statute. The national legislature, on the other hand, remains the principal of local government units, which cannot defy, alter, or breach its will (citing Magtajas v. Pryce Properties Corp. 234 SCRA 255) [21]

At issue in said case is the validity of a local legislation enacted by the SangguniangPanlalawigan of Laguna, which vehemently objected to the operation of lotto in the province, and became basis of the denial by the Mayor of San Pedro of an application for permit to operate lotto filed by the private respondent. The petitioners alleged that such legislation is a valid exercise of police power under the General Welfare Clause of RA 7160. The Court declared such position untenable, explaining that lotto is a game of chance duly authorized by Congress in RA 1169, as amended by Batas PambansaBlg. 42 and that local ordinances cannot go against laws passed by Congress, since "the power of local government units to legislate and enact ordinances and resolutions is merely a delegated power coming from Congress." It stressed further that: 
Municipal councils are nothing more than servants of the federal government. Local governments only have constitutional authority that has been assigned to them by Congress, the nation's legislative body. The delegate cannot be more powerful than the principal or have more authority than the others. It is heresy to say that local government units would revoke Congress's actions, from which they derived their authority in the first place, and eliminate the statute's provision with a simple ordinance.

Municipal companies owe their existence to the government, which therefore grants them all of their privileges and privileges. It gives them life, which they wouldn't have if it weren't for it. It can ruin what it makes. It has the ability to abridge and manipulate as well as kill. Unless there is some procedural restriction on the right, the government could, in a single act, and if we can imagine it worthy of such stupidity and wrongdoing, wipe out all of the state's local companies, and the corporations will be unable to stop it.In terms of the company itself, we are unaware of any restrictions on the right. They are, to put it another way, the legislature's mere tenants at will (citing Clinton vs. Ceder Rapids, etc. Railroad Co., 24 Iowa 455).

The same conclusion was reached by the Court in Basco v. PAGCOR, which similarly deals with gambling, as noted above.

The Davao City SangguniangPanlungsod passed an ordinance prohibiting all agricultural institutions in the city from using aerial spraying as a farming activity. The ordinance was forced by the respondents because it disregarded certain Fertilizer and Pesticide Authority laws. Sustaining the contention of the respondents, the Court explained:

Despite the fact that the Local Government Code gives municipal corporations enough autonomy to regulate themselves and administer their affairs and operations, they have no authority to pass regulations that contradict state laws and policies. The aim of the Local Government Code was to describe the general parameters and restrictions that each local government unit would obey when exercising its delegated powers, with the goal of converting the local government unit into a fully functioning subdivision of the state while staying within statutory and legislative constraints. 175 The Local Government Code does not grant a local government agency blanket power to legislate on any matter it deems appropriate in the name of promoting the public interest.

$x x x$

Certainly, Congress is the only source of regulatory power for each local government entity. The local government entity will never be more powerful than the source of its power. As a result, the ordinance cannot conflict with or violate established statutes, precisely because its jurisdiction is derived solely from Congress's valid delegation. [22]

And whenever LGUs exercise powers delegated to it by Congress, the former must strictly comply with the statutory requirements. In exercising the power of eminent domain, the SangguniangPanlungsod of Mandaluyong City issued a resolution authorizing the City Mayor to institute expropriation proceedings over a private property. After differentiating "resolution" as a mere declaration of sentiment of opinion of a sanggunianon a matter, from "ordinance" which is a law, the Court annulled the expropriation proceedings, because the Local Government Code of 1991 clearly and specifically requires an ordinance, and not a resolution, for purposes of exercising the power of eminent domain. The Court said:

(W)hileWe can't give judicial permission to a municipal government agency exercising its delegated right of eminent domain in violation of the statute that gave it that power. [23]

Tested in Ferrer vs. Bautista was the exercise of taxation and police power of a city. The Quezon City Council passed an ordinance requiring the collection of garbage fees from residential properties, which must be collected entirely and entirely in a separate fund 
designated for garbage collection. The Court struck down such provision of the ordinance for being inconsistent with Section 10 of RA 9003, which limits the responsibility of a city to the collection of non-recyclable materials and special wastes. The ordinance imposed garbage fee based on the volume of waste generated by each person in Quezon City, without regard for the specific types of wastes [24].

Congress, however, will not be upheld in the exercise of control over LGUs when it already transgresses the constitutional policy of local autonomy. In the case of Film Development Council v. Colon Heritage Realty Corporation, the Court was asked to resolve a dispute between the inherent taxing power of Congress and the power to tax delegated to local governments. In 1993, the City of Cebu enacted amusement taxes of thirty percent (30\%) of total admission fee receipts on owners, lessees, or managers of theatres, cinemas, concert halls, circuses, boxing stadia, and other amusement venues. The Film Development Council of the Philippines (FDCP)was established by RA 9167, passed by Congress in 2002. It also stated that income from the graded film amusement tax, which would otherwise go to cities and towns, would be withdrawn and remitted to the Council by the proprietors, owners, or lessees of theatres or cinemas. While admitting that the power of taxation is purely legislative, it can be validly delegated to municipal corporations. Quite interestingly, the Court said:

... It is important that Congress, rather than the taxing body, earmarked, if not completely confiscated, the money received by the LGU from people in favour of and for transfer to FDCP. This, in our view, is in gross breach of the constitutional provision that taxes levied by $L G U$ s accrue exclusively to that $L G U$, which is incompatible with the right of $L G U$ s to distribute funds according to their own desires.

The natural legislative powers of Congress are constrained and preserved within the four walls of the Constitution, which is a foundational principle.As a result, if the government uses the authority to pass, modify, or repeal statutes, it shall do so within the bounds set out by organic statute. [25]

\section{Conclusion}

How Philippine local governments behave vis-à-vis the executive and legislative branches of the national government within the legal framework changed in recent politicoadministrative history. With the constitutional policy of local autonomy and the enactment by Congress of the enabling law, the Local Government Code of 1991, local governments were obviously given more powers, functions and responsibilities that were formerly concentrated at, if not monopolized, by the national government. This does not mean, though, that local governments are completely autonomous, absolutely free from any interference, especially that coming from the executive and legislative branches.

This paper unveiled that the Supreme Court, in applying and interpreting the law, is not ready to accept the view that local autonomy means creating empires within an empire, but that of restricted decentralization, where local governments enjoy autonomy, but remain under the general supervision of the President and an attenuated control by Congress. The Constitution and the law remains the "North Star" of the Supreme Court in interpreting the concept of local autonomy.Among the objectives of Filipino-type of decentralization are to break the narrative of a highly centralized governmental design, and create sublevel units that are more responsive to the needs of the immediate locality, but still within the context of national development. As elucidated by the eminent Justice Isagani Cruz, as cited in a case, 
"(a)utonomy does not, after all, contemplate making mini-states out of local government units." The case further elaborated:

... In the fact that the legislature's legislative responsibility-as the "supervision clause" itself suggests-is to wean local government bodies from over-reliance on the central government, autonomy, in the constitutional sense, is subject to the legislature's guiding light, but not control.

The foregoing findings are suggestive of the need for constitutional revision, not merely amendment, if the direction is to introduce substantive reforms to weaken or deepen local autonomy. The decisions promulgated thus far by the Supreme Court underscore a limited form of decentralization, such that any attempt to break away from the current setup will necessarily entail meaningful changes on the relations between the local governments on the one hand, and the executive and legislative branches, on the other. If these reforms would amount to a shift from the unitary to a federal setup, constitutional amendment is not enough, much less a mere amendment of the Local Government Code 1991. The proper manner or method of institutionalizing any reform, from mere statutory amendment to the more arduous constitutional revision, would depend on the extent and degree of the desired changes.

Whither the centre-periphery relations should proceed is a political issue left to the discretion of the political agencies and ultimately the sovereign, and is beyond the competence of the Supreme Court to resolve.

\section{Acknowledgments}

The authors would like to acknowledge the unconditional support from the College of International Relations, Lyceum of the Philippines University.

\section{References}

[1] Alex B. Brillantes, Jr. 2003.Innovations and Excellence: Understanding Local Governments in the Philippines. 8.

[2] Proserpina Domingo Tapales. 2003. The Nature and State of Local Government.Public Administration in the Philippines: A Reader. 315-316.

[3] Brillantes, A.B. 2003. Decentralized Democratic Governance Under the Local Government Code: A Governmental Perspective. Public Administration In The Philippines: A Reader.324.

[4] ShabbirCheema, A. and Rondinelli, Dennis A. 1983. Decentralization and Development: Policy Implementation in Developing Countries. 16.

[5] Einsiedel, N. 2002. Overcoming the Obstacles to Decentralization in Asia, Philippine Journal of Public Administration. 25-38.

[6] Cariño, L. 1998. Governance in Local Communities: Towards Development and Democracy. The Local Government In The Philippines: A Book Of Readings. 7.

[7] Haryanto, Lay, C., \&Purwoko, B. (2017). Asymmetrical Decentralization, Representation, and Legitimacy in Indonesia. Asian Journal of Political Science, 25(1), 130-50.

[8] Manila Prince Hotel v. GSIS, G.R. No. 122156, February 3, 1997.

[9] San Juan v. CSC, G.R. No. 9229, April 19, 1991.

[10] Basco v. Philippine Amusement and Gaming Corp., G.R. No. 91649, May 14, 1991.

[11] Ganzon v. Court of Appeals, G.R. Nos. 93252, 93746 \& 95245, August 5, 1991

[12] National Ligangmga Barangay v. Paredes, G.R. Nos. 130775 \& 131939, September 27, 2004.

[13] Taule v. Santos, G.R. No. 90336, August 12, 1991.

[14] G.R. Nos. 130775 \& 131939, September 27, 2004. 
[15] G.R. No. 132988, July 19, 2000.

[16] The Province of Batangas v. Romulo, G.R. No. 152774, May 27, 2004.

[17] Dadole v. Commission on Audit, G.R. No. 125350, December 3, 2002.

[18] G.R. No. 100152, March 31, 2000.

[19] G.R. No. 182604, September 27, 2016.

[20] Hague, R. and Harrop, M. 2004. Comparative Government And Politics: An Introduction. 229 and 236.

[21] G.R. No. 129093, August 30, 2001.

[22] Mosqueda v. 2016. Pilipino Banana Growers an Exporters Association, Inc., G.R. Nos. 189185 \& 189305, August 16, 2016.

[23] Heirs of Suguitan v. City of Mandaluyong, G.R. No. 135087, March 14, 2000.

[24] G.R. No. 210551, June 30, 2015.

[25] G.R. Nos. 203754 \& 204418, June 16, 2015. 